DIKLUS: Jurnal Pendidikan Luar Sekolah

Nomor 2 (volume 3), September 2019 - 103

\title{
Pengelolaan Program Perlindungan Anak Terpadu Berbasis Masyarakat (PATBM)
}

\author{
Ratih Setyawati \\ Pendidikan Nonformal, Universitas Negeri Yogyakarta \\ rthsetyawati@gmail.com
}

\begin{abstract}
Abstrak
Tujuan penelitian ini adalah untuk mendeskripsikan pengelolaan program Perlindungan Anak Terpadu Berbasis Masyarakat (PATBM) Desa Ngalang, untuk mendeskripsikan manfaat program PATBM Desa Ngalang, dan mendeskripsikan faktor penghambat dalam pelaksanaan program PATBM Desa Ngalang. Penelitian ini adalah penelitian kualitatif dengan jenis penelitian desktiptif. Subjek penelitian ini adalah ketua PATBM Desa Ngalang, aktivis PATBM Desa Ngalang, dan kelompok sasaran program, yaitu anggota Forum Anak Desa (FAD) Ngalang dan orang tua mereka. Teknik pengumpulan data yang digunakan adalah observasi, wawancara, dan dokumentasi. Uji keabsahan data dilakukan dengan triangulasi sumber data. Teknik analisis data yang digunakan adalah reduksi data, penyajian data, dan penarikan kesimpulan. Hasil penelitian menunjukkan bahwa: Pertama, pengelolaan program PATBM Desa Ngalang meliputi perencanaan, pengorganisasian, pengimplementasian, monitoring dan evaluasi. Kedua, manfaat dari PATBM Desa Ngalang yaitu adanya peningkatan kesadaran orang tua dalam pemenuhan hak-hak anak dan membantu perkembangan anak. Segi kognitif: anak mampu mengutarakan pendapatnya secara kritis, anak bertambah pengetahuannya tentang hak dan perlindungan anak, dan anak memiliki inisiatif untuk melaporkan. Segi sosial: anak memiliki pergaulan yang positif, kemampuan beradaptasi dengan lingkungan baru, kepedulian anak terhadap orang lain, dan anak-anak menjadi lebih percaya diri. Segi moral: anak memiliki tata krama terhadap orang lain dan ada perubahan akhlak ke arah yang baik. Ketiga, faktor penghambat pelaksanaan PATBM Desa Ngalang berasal dari faktor internal yaitu sumber daya manusia PATBM Desa Ngalang dan pendanaan yang terbatas. Solusi dari hambatan yang terjadi adalah memanfaatkan media sosial untuk berkoordinasi dan lebih sering bergabung dengan kegiatan yang sudah ada di masyarakat.
\end{abstract}

Kata Kunci: Pengelolaan Program, PATBM, Manfaat, Perlindungan Anak

\section{Abstract}

The purpose of this research are to describe the management program of Perlindungan Anak Terpadu Berbasis Masyarakat (PATBM) Desa Ngalang, to describe the benefits of PATBM Desa Ngalang program, to describe the barrier factors in performing of PATBM Desa Ngalang. The research is a qualitative research with a descriptive research type.The subjects of this research are the leader of PATBM Desa Ngalang, the activist of PATBM Desa Ngalang, and the target group of PATBM Desa Ngalang: the member of Forum Anak Desa (FAD) Ngalang and their parents. Data collection techniques used were observation, interviews, and documentation. The data validity test was done by triangulation data source. The data analysis technicques used were data reduction, a data presentation, and a conclusion. The results of the research show that: First, the management program of the PATBM Desa Ngalang includes planning, organizing, implementation, monitoring and evaluation. Second, the benefits of the PATBM Desa Ngalang, such as there is an increasing of parents' awareness in fulfilling children's rights and for helping children development. Cognitive aspect : children are able to express their 


\section{Diklus: Jurnal Pendidikan Luar Sekolah, 2 (3), September 2019 - 104 \\ Ratih Setyawati}

opinions critically, children have increased their knowledge about rights and protection of children, children are able to defend themselves when their rights are violated, and children have initiatives to report. Social aspect: children have positive relationships, children are able to adapt to new environments, children have concern for others, and children become more confident. Morals aspect: children have good manners towards others and there is a change in morals in a good direction. Third, the barrier factors for the implementation of PATBM Desa Ngalang come from internal, that is human resources of PATBM Desa Ngalang and limited funding. The solution to the obstacles that occurred was utilizing social media to coodinate and to more often join with activities that already exist in the community.

Keywords: Management of Program, PATBM, Benefits, Children Protection

\section{PENDAHULUAN}

Anak adalah bagian dari anggota masyarakat yang berada dalam kategori cukup rentan menjadi korban tindak kekerasan. Maharani (2015: 13-18) menyebutkan bahwa ada lima jenis-jenis kekerasan yang umum terjadi terhadap anak yaitu kekerasan fisik, kekerasan seksual, kekerasan psikis, penelantaran, dan bullying. Banyaknya kasus kekerasan terhadap anak menadakan masih banyak yang tidak peduli dan belum paham terhadap hak-hak anak. Ketidaktahuan seseorang bahwa tindakan yang dilihat atau dilakukannya merupakan kekerasan juga memicu terjadinya tindakan kekerasan terhadap anak.

Komisi Pelindungan Anak Indonesia (KPAI) mencatat, kasus pelanggaran hak terhadap anak pada tahun 2018 mencapai 4.885 kasus. Jumlah ini meningkat dibandingkan pada tahun 2017 yang mencapai 4.579 kasus (www.kpai.go.id). Kasus kekerasan terhadap anak juga terjadi di Kabupaten Gunungkidul, Yogyakarta. Berdasarkan data yang diperoleh oleh peneliti dari Forum Perlindungan Korban Kekerasan Perempuan dan Anak (FPK2PA) Kabupaten Gunungkidul tercatat ada 105 kasus tindakan kekerasan terhadap anak selama tahun 2015 hingga tahun 2018. Kasus tersebut tergolongkan menjadi empat jenis kekerasan yaitu 10 kasus kekerasan fisik, 12 kasus kekerasan psikis, 69 kasus kekerasan seksual, dan 11 kasus penelantaran anak.

Pemerintah membuat undangundang tentang perlindungan anak sebagai langkah untuk mencegah tindakan kekerasan terhadap anak dan melindungi hak-haknya. UndangUndang Nomor 23 Tahun 2002 tentang Perlindungan Anak Pasal 1 Ayat 2 menentukan bahwa perlindungan anak adalah segala kegiatan untuk menjamin, dan melindungi anak dan hak-haknya agar dapat hidup, tumbuh dan berkembang, dan berpartisipasi, secara optimal sesuai dengan harkat dan martabat kemanusiaan, serta mendapat perlindungan dari kekerasan dan diskriminasi. Gultom (2008: 34) mengartikan perlindungan anak sebagai segala upaya yang bertujuan mencegah, rehabilitasi, dan memberdayakan anak yang mengalami perlakuan salah (child abuse), eksploitasi, dan penelantaran, agar dapat menjamin kelangsungan hidup dan tumbuh kembang anak secara wajar baik fisik, mental, dan sosialnya.

Kementerian Pemberdayaan Perempuan dan Perlindungan Anak (KPPPA) pada tahun 2015 menggagas program Perlindungan Anak Terpadu Berbasis Masyarakat (PATBM). PATBM merupakan gerakan perlindungan anak yang dikelola oleh sekelompok orang yang tinggal di suatu wilayah (desa/kelurahan). Melalui PATBM, masyarakat diharapkan mampu 
mengenali, menelaah, dan mengambil inisiatif untuk mencegah dan memecahkan permasalahan kekerasan terhadap anak yang ada di lingkungannya sendiri. Hal ini sesuai dengan konsep pendidikan masyarakat menurut Surakhmad dalam Suharto (2005: 335) bahwa pendidikan berbasis masyarakat merupakan usaha peningkatan rasa kesadaran, kepedulian, kepemilikan, keterlibatan, dan tanggung jawab masyarakat.

Pada awal tahun 2016 di KPPPA membentuk dua PATBM di Kabupaten Gunungkidul sebagai percontohan yaitu di Desa Ngalang, Kecamatan Gedangsari dan Desa Kemadang, Kecamatan Tanjungsari. Pembentukan PATBM ini juga untuk mendukung program pemerintah Gunungkidul menuju Kabupaten Layak Anak. PATBM lain yang dijadikan percontohan di Kota Yogyakarta adalah PATBM Brontokusuman. Pelaksana Tugas (PLT) Kepala Dinas Pemberdayaan Perempuan dan Perlindungan Anak (DPMPPA) Kota Yogyakarta mengungkapakan bahwa Kelurahan Brontokusuman dipilih karena di sana ada masalah serta potensi warga yang bisa bersinergi untuk menghadapi masalah yang berkaitan dengan anak pada. Tahun 2018 kemudian ada 20 kelurahan yang menjalankan PATBM di Kota Yogyakarta.

$$
\text { Kabid Perlindungan Anak }
$$

DP3AKBPM\&D Kabupaten Gunungkidul (Bapak TM) melalui wawancara pra penelitian, mengungkapkan bahwa pihaknya akan membentuk kembali PATBM di Kabupaten Gunungkidul. Tahun 2017 Bidang Pelindungan Anak telah membentuk PATBM di Desa Banaran, Kecamatan Playen. Kemudian untuk tahun 2019 akan dibentuk kembali PATBM di Kecamatan Patuk. Output dari pembentukan PATBM ini adalah turunnya angka kekerasan di Kabupaten Gunungkidul.

PATBM Desa Ngalang yang terlebih dulu dibentuk, dapat dijadikan percontohan untuk PATBM yang baru dibentuk. Keberadaan PATBM mendukung Desa Ngalang dalam mendapatkan penghargaan Desa Layak Anak tingkat Kabupaten Gunungkidul pada tahun 2017. Sebagai percontohan maka organisasi tersebut harus dikelola secara efektif. Menurut James L. Gibson dalam Agung Kurniawan (2005: 107) ada delapan indikator efektivitas organisasi, yaitu adanya kejelasan tujuan yang hendak dicapai, kejelasan strategi pencapaian tujuan, proses analisis dan perumusan kebijakan yang mantap, perencanaan yang matang, tersedianya sarana dan prasarana, pelaksanaan yang efektif dan efisien, sistem pengawasan dan pengendalian. Untuk mengelola sebuah program ada menurut Fuad (2014: 24) empat fungsi dasar manajemen program yaitu perencanaan, pengorganisasian, pengimplementasian, dan pengendalian (monitoring dan evaluasi).

Bapak ES selaku Kesra Desa Ngalang melalui wawancara pra penelitian mengungkapkan bahwa dalam pengelolaan PATBM Desa Ngalang dikelola oleh masyarakat setempat dari berbagai unsur yaitu dari tokoh agama, pendidik, PKK, kesehatan, dan KUA. Keberadaan PATBM Desa Ngalang menjadi embiro lahirnya Forum Anak Desa (FAD) Ngalang. Keberadaan FAD ini akan memperkuat pemerintah untuk melakukan pencegahan tidak kekerasan pada anak. Dari awal pembentukan PATBM Desa Ngalang beberapa kegiatan telah dilakukan terpadu mulai dari promosi dan pencegahan, penanganan dan rehabiliasi, kegiatan tersebut berupa sosialisasi perlindungan dan pola asuh anak di beberapa dusun di Desa 
Ngalang, pendampingan FAD Ngalang, Deklarasi Pencegahan Pernikahan Usia Dini, Pemanfaatan Gagdet Secara Positif, Stikerisasi Rumah (pemasangan indikator keluarga yang punya anak), Kresekisasi (pemasangan indikator keluarga yang memiliki remaja perempuan), dan masih ada beberapa program lainnya.

Pada tahun 2017 Desa Ngalang masih mencatat ada sebanyak satu kasus kekerasan fisik terhadap anak. Dalam kasus yang terjadi, PATBM Desa Ngalang berperan mengupayakan pendampingan dan mencarikan tempat singgah yang aman dan dijauhkan dari pelaku. Di tahun 2018 Desa Ngalang kembali mencatat satu kasus, dimana pelaku dan korban sama-sama berada pada usia anak. Masih ada lagi tindak kekerasan yang terjadi tetapi tidak dilaporakan oleh yang bersangkutan, selain karena anggapan bawah hal tersebut adalah aib sehingga harus ditutupi, masyarakat juga tidak paham bahwa yang bersangkutan adalah korban dari tindak kekerasan. Potensi tindak kekerasan masih memungkinkan terjadi, faktor penyebabnya adalah masih kurangnya kesadaran pribadi untuk tidak melakukan tindak kekerasan walaupun PATBM Desa Ngalang sudah berusaha memberikan sosialisasi. Kasus kekerasan anak yang masih terjadi di Desa Ngalang ini menjadi PR bagi PATBM Desa Ngalang untuk terus mengedukasi dari tingkat anak hingga ditingkat komunitas masyarakat.

PATBM Desa Ngalang dalam mengelola program masih mengalami kendala. Kendala ini berasal dari pengurus PATBM Desa Ngalang dimana kesibukan pengurus PATBM Desa Ngalang menjadikan kegiatan berjalan kurang maksimal. Selain itu, keterbatasan dana juga menjadi kendala PATBM Desa Ngalang untuk membuat acara-acara besar. Program dilaksanakan juga harus menungggu turunnya dana APBDes Ngalang. Namun, untuk beberapa kegiata PATBM Desa Ngalang dapat bergabung dengan kegiatan di masyarakat yang sudah ada sebelumnya sehingga tidak perlu mengeluarkan dana. Berdasarkan uraian di atas maka peneliti akan melakukan penelitian untuk mengetahui bagaimana pengelolaan program PATBM Desa Ngalang agar dapat dijadikan percontohan PATBM-PATBM yang baru terbentuk. Penulis akan melakukan penelitian dengan judul: Pengelolaan Program Perlindungan Anak Terpadu Berbasis Masyarakat (PATBM) Desa Ngalang, Gedangsari, Gunungkidul. Penelitian ini dirasa penting guna menambah wawasan masyarakat dan PATBM yang baru dibentuk terkait pengelolaan, manfaat PATBM dalam mengupayakan perlindungan anak secara terpadu, dan kendala-kendala yang mungkin terjadi sehingga dapat diantispasi sebelumnya. Dengan keberadaan PATBM diharapkan mampu memotivasi masyarakat dan semua pihak untuk turut andil dalam meyuarakan perlindungan terhadap anak.

\section{METODE}

Penelitian ini merupakan jenis penelitian deskriptif dengan menggunakan pendekatan kualitatif. Penelitian ini mendeskripsikan bagaimana pengelolaan program Perlindungan Anak Terpadu Berbasis Masyarakat (PATBM) Desa Ngalang, Gedangsari, Gunungkidul dalam mencegah dan menanggapi masalah kekerasan terhadap anak melalui data yang diperoleh dari subjek penelitian.

Penentuan subjek penelitian dipilih dengan cara purposive sampling. Subjek dalam penelitian ini adalah a) ketua PATBM Desa Ngalang; b) aktivis 
PATBM Desa Ngalang; c) kelompok sasaran (anggota forum anak Desa Ngalang dan orang tua anggota forum anak Desa Ngalang).

Teknik pengumpulan data yang digunakan dalam penelitian ini yaitu Observasi

Observasi dalam penelitian ini menggunakan metode observasi partisipasi pasif. Observasi dilakukan dengan tujuan untuk memperoleh data mengenai pengelolaan program PATBM Desa Ngalang melalui berbagai kegiatannya dalam mengupayakan pencegahan dan menanggapi tindak kekerasan terhadap anak di Desa Ngalang.

Wawancara

Teknik wawancara yang digunakan dalam penelitian ini adalah wawancara terstrukrur dan wawancara semi terstruktur. Kedua teknik ini dipilih untuk mengali informasi secara mendalam terkait pengelolaan program Perlindungan Anak Terpadu Berbasis Masyarakat (PATBM) Desa Ngalang, Gedangsari, Gunungkidul. Wawancara dalam penelitian ini dilakukan kepada ketua PATBM Desa Ngalang, aktivis PATBM Desa Ngalang, kelompok sasaran (anggota Forum Anak Desa Ngalang dan orang tua anggota forum anak Desa Ngalang).

Dokumentasi

Dokumentasi dalam penelitian ini berupa sejarah berdirinya PATBM Desa Ngalang, visi san misi, foto kegiatan, data sarana dan data pengurus, laporan kegiatan, data pendukung lain mengenai keberadaan PATBM Desa Ngalang, Gedangsari, Gunungkidul.

Uji keabsahan data dalam penelitian ini menggunakan triangulasi sumber. Dari hasil uji keabsahan data melalui triangulasi peneliti dapat membandingkan informasi tentang hal yang sama, yang diperoleh dari berbagai sumber data yang berbeda. Langkah ini dilakukan untuk menghindari subjektivitas dari peneliti, sehingga hasil penelitian ini valid dan dapat dipertanggungjawabkan.

Teknik analisis data yang digunakan dalam penelitian ini adalah interaktif model Miles \& Huberman (Sugiyono, 2015:246), aktivitas dalam analisis data kualitatif dilakukan secara terus menerus sampai tuntas, sehingga datanya sudah jenuh. Aktivitas analisis data dalam penelitian ini ada empat tahap, yaitu data collection, data redution, data display, dan data conclusion drawing/verification.

\section{HASIL DAN PEMBAHASAN}

Perlindungan Anak Terpadu Berbasis Masyarakat (PATBM) Desa Ngalang adalah lembaga yang dibentuk berdasarkan Surat Keputusan Kepala Desa Ngalang yang berperan dalam rangka perlindungan dan pemenuhan hak-hak anak menuju pembanguan diwilayah Desa Ngalang yang peduli terhadap anak. Secara formal menurut ADART PATBM Desa Ngalang berdiri pada tanggal 1 Agustus 2016. Alamat PATBM ini adalah di Desa Ngalang, Gendangsari, Gunungkidul.

PATBM Desa Ngalang memiliki visi untuk "Mewujudkan PATBM Desa Ngalang menjadi mitra pemerhati anak." Dalam menjalankan visi tersebut misi yang dilakukakan PATBM Desa Nalang adalah : 1) memenuhi hal-hak anak, 2) pelayanan pengaduan masalah anak, 3) pendampingan korban kekerasan anak, 4) menekan angka pernikahan usia anak, 5) kepenyuluhan keluarga di semua lingkungan anak untuk membina keluarga yang harmonis dan sejahtera.

Program yang dilakukan PATBM Desa Ngalang adalah mencegah dan menanggapi tindak kekerasan terhadap anak. Kegiatan yang dilakukan untuk 
mencegah tindak kekerasan terhadap anak yaitu Kampanye Stop Kekerasan terhadap Anak, Pembentukan dan Pendampingan Forum Anak Desa Ngalang, Sosialisasi Perlindungan dan Pola Asuh Anak, dan Deklarasi Pencegahan Pernikahan Usia Dini. Sedangkan kegiatan untuk menanggapi tindak kekerasan terhadap anak dilakukan dengan memberikan pelayanan pengaduan masalah anak dan pendampingan korban kekerasan anak.

\section{Pengelolaan Program PATBM Desa Ngalang \\ a. Perencanaan Program PATBM Desa Ngalang \\ Perencanaan program PATBM} Desa Ngalang dilaksanakan pada saat pada rapat kerja tahunan, yaitu setiap awal tahun. Dalam proses perencanaan program PATBM Desa Ngalang ada beberapa pihak yang terlibat. Adapun pihak-pihak yang terlibat yaitu pengurus PATBM Desa Ngalang dan tokoh masyarakat. Hal ini sesuai dengan pendapat Surakhmad dalam Suharto (2005: 335) bahwa konsep pendidikan berbasis masyarakat merupakan usaha peningkatan rasa kesadaran, kepedulian, kepemilikan, keterlibatan, dan tanggung jawab masyarakat.

Majid (2018: 15) berpendapat bahwa perencanaan merupakan penyusunan langkah-langkah yang akan dilaksanakan dalam mencapai tujuan yang sudah ditentukan sebelumnya. Sesuai dengan pendapat Majid, PATBM Desa Ngalang membuat perencanaan program terlebih dahulu dalam rapat kerjanya. Adapun yang direncanakan oleh PATBM Desa Ngalang, yaitu diawali dengan identifikasi kebutuhan, perumusan dan penetapan program, sumber dana, sarana dan prasarana.

Proses perencanaan program PATBM Desa Ngalang dimulai dengan melakukan identifikasi kebutuhan.
Pengurus PATBM melakukan identifikasi kebutuhan berdasarkan hasil informasi yang diperoleh dari masyarakat dan tokoh masyarakat. Informasi dari masyarakat ini diperoleh dari kegiatankegiatan desa yang sudah ada sebelumnya, seperti kegiatan PKK, arisan RT, dan sebagainya. Informasi yang didapat dari masyarakat ini kemudian didiskusikan oleh para pengurus PATBM. Pengurus melakukan identifikasi prioritas kebutuhan untuk selanjutnya dijadikan dasar dalam penetapan program.

Proses identifikasi kebutuhan dilakukan oleh pengurus melalui diskusi yang dipimpin oleh ketua PATBM. Pengurus akan menyampaikan apa saja informasi yang diperoleh dari masyarakat mengenai isu-isu yang berkembang terutama potensi terjadinya permasalahan tidak kekerasan terhadap anak. Kemudian pengurus akan mendiskusikan hasil penyampaian masalah dari para pengurus. Dari berbagai masalah yang ada, akan ditentukan mana yang menjadi prioritas. Sekretaris akan membuat notulen dari diskusi kemudian sekretaris akan menyampaikan kesimpulan dari hasil diskusi tersebut.

Setelah melakukan identifikasi kebutuhan dan mendiskusikannya, tahap selanjutnya dalah perumusan program. Dalam menetapkan program mengacu pada permasalahan yang terjadi di masyarakat terkait dengan upaya perlindungan terhadap anak. Program yang telah dirumusakan tersebut akan disosialisasikan kepada masyarakat. Sosialisasi kebijakan pelaksanaan program PATBM dilakukan dengan cara mengumpulkan warga, melalui kegiatan warga yang sudah ada sebelumnya dan melalui tokoh-tokoh masyarakat. Sasaran kegiatan PATBM Desa Ngalang dibagi menjadi tiga, yaitu tingkat 
masyarakat/komunitas, tingkat keluarga, dan tingkat anak. Pada tingkat masyarakat/komunitas ada program Kampanye Stop Kekerasan terhadap Anak dan Deklarasi Pencegahan Pernikahan Usia Dini dilakukan satu kali, yaitu pada awal pembentukan PATBM Desa Ngalang. Pada tingkat keluarga yang dilakukan melalui kegiatan Sosialisasi Perlindungan dan Pola Asuh Anak dilakukan lebih rutin dan fleksibel dengan mengikuti kegiatan organisasi yang ada dimasyarakat, seperti kegiatan PKK. Pada tingkat PATBM Desa Ngalang mentargetkan paling tidak dalam satu tahun ada dua sampai tiga kali kegiatan sosialisasi mengenai upaya melindungi dan mecegah tindak kekerasan terhadap anak melalui pendampingan yang dilakukan kepada FAD Ngalang.

Pelaksanaan program PATBM

Desa Ngalang dibiayai oleh APBEDes. Program kerja yang telah ditetapkan dalam rapat kerja akan diusulkan saat Musyawarah Perencanaan Pembangunan Desa (Musregbangdes). Berdasarkan penelitian yang dilakukan dana untuk melakukan kegiatan sudah mecukupi. Karena sifat dari lembaga PATBM Desa Ngalang adalah sosial berbasis masyarakat dalam pelaksanaan kegiatannya bisa bergabung dengan kegiatan yang sudah ada. Oleh karena itu, dalam pelaksanaannya PATBM Desa Ngalang juga mendapatkan swadaya dari masyarakat berupa snack untuk konsumsi. Pengalokasian dana dari APBDes tersebut dikelola cukup baik oleh pengurus PATBM. Pengurus dapat meminimalisir pengeluaran karena untuk pemateri mereka tidak perlu mengeluarkan dana. Jadi, sebagian besar dana dialokasikan untuk biaya adminstrasi dan biaya konsumsi.

Sarana dan prasarana yang dimiliki PATBM Desa Ngalang cukup memadai. Untuk melakukan sosialisasi kepada masyarakat keberadaan tempat pertemuan seperti Balai Desa Ngalang, Rumah Pintar Ngalang, dan Rest Area Gubug Gedhe sangat mendukung pelaksanaan kegiatan. Bantuan sarana oleh KPPPA juga sangat mendukung PATBM untuk menyampaikan materi. Dilihat dari hasil observasi, pemerintah juga sangat mendukung dengan kebijakannya untuk menciptakan kawasan yang ramah anak dengan plangplang himbuan untuk melindungi anak dari hak-haknya dan himbauan untuk tidak melakukan tindak kekerasan terhadap anak.

Tabel 1. Pengelolaan Program PATBM Desa Ngalang

\begin{tabular}{|c|c|}
\hline Aspek & Hasil \\
\hline Perencanaan & \begin{tabular}{l}
\multicolumn{2}{c}{ Perencanaan } \\
program dilakukan pada \\
saat rapat kerja dengan \\
melibatkan pengurus dan \\
tokoh-tokohr masyarakat. \\
Kompenen $r$ dalam \\
perencanaan program \\
PATBM Desa Ngalang, \\
yaitu: \\
identifikasi kebutuhan, \\
perumusan ran \\
penetapan dan \\
sumber dana, sarana dan \\
prasarana.
\end{tabular} \\
\hline Pengorganisasian & $\begin{array}{l}\text { Komponen } \\
\text { pengorganisasian yang } \\
\text { dilakukan oleh PATBM } \\
\text { Desa Ngalang yaitu } \\
\text { penetapan struktur } \\
\text { organisasi dan pembagian } \\
\text { tugas, perekrutan sumber } \\
\text { daya pelaksana program, } \\
\text { penempatan sumber daya } \\
\text { dalam implementasi } \\
\text { program, pemotivasian, } \\
\text { penentuan sumber daya } \\
\text { manusia yang diperlukan, } \\
\text { proses pemotivasian. }\end{array}$ \\
\hline
\end{tabular}




\begin{tabular}{|c|c|}
\hline $\begin{array}{l}\text { Pegimplementasia } \\
\text { n }\end{array}$ & \begin{tabular}{l}
\multicolumn{2}{c}{ Komponen } \\
pengimplementasian \\
program yang harus \\
diperhatikan yaitu, proses \\
pembelajaran yang \\
dilakukan, ry peran \\
narasumber, dan suasana \\
pembelajaran.
\end{tabular} \\
\hline $\begin{array}{l}\text { Monitoring dan } \\
\text { Evaluasi }\end{array}$ & \begin{tabular}{lcr}
\multicolumn{3}{c}{ Monitoring } \\
dilakukan oleh & KPPPA \\
dan & DP3AKBPM\&D \\
Kabupaten Gunungkidul, \\
setiap satu tahun sekali \\
pada awal tahun. Evaluasi \\
yang dilakukan & oleh \\
pengurus & PATBM Desa \\
Ngalang hanya sebatas \\
evaluasi & \multicolumn{2}{c}{ program, } \\
sedangkan & evaluasi \\
pembelajaran & tidak \\
dilaksanakan. & Evalausi \\
program dilakukan saat & rapat & koordinasi \\
pengurus & setiap bulan \\
setelah & \multicolumn{2}{c}{ pelaksanaan } \\
program.
\end{tabular} \\
\hline
\end{tabular}

\section{b. Pengorganisasian PATBM Desa Ngalang}

Program

Komponen pengorganisasian yang dilakukan oleh PATBM Desa Ngalang meliputi pembuatan struktur organisasi/lembaga dan pembagian tugas, perekrutan sumber daya pelaksana program, penempatan sumber daya pelaksana dalam implementasi program, pemotivasian, dan pemberian reward/punishment. Temuan ini sejalan dengan pendapat Fuad (2014: 207) bahwa pengorganisasian, terdiri dari pengalokasian sumber daya, perumusan dan penetapan tugas serta penetapan prosedur; penetapan struktur organisasi yang menunjukkan adanya garis kewenangan dan tanggung jawab,kegiatan perekrutan, penyelekasian, pelatihan dan pengembangan sumber daya tenaga; serta penempatan sumber daya manusia pada posisi yang paling tepat.
Bagian terpenting dalam proses pengorganisasian yang harus dilakukan oleh organisasi atau lembaga adalah membentuk struktur organisasi. Penetapan struktur organisasi didasarkan pada kebutuhan program yang akan diselenggarakan oleh organisasi. Berdasarkan hasil penelitian, struktur organisasi PATBM Desa Ngalang terdiri dari beberapa bagian, yaitu pelindung, ketua, sekretaris, bendahara, seksi pemberdayaan SDM, seksi humas, dan seksi logistik. Dari pengurus PATBM Desa Ngalang tersebut telah memenuhi elemen-elemen yang harus ada berdasarkan intruksi dari KPPPA, yaitu terdiri dari tokoh masyarakat, perangkat desa, tokoh agama, pendidik, PKK, kesehatan, KUA.

Tahap selanjutnya adalah perekrutan sumber daya sebagai pelaksana dari program yang telah ditentukan oleh organisasi atau lembaga. Sumber daya pelaksana program ini dibagi menjadi dua, yaitu panitia kegiatan dan narasumber. Dalam pelaksanaan program panitia kegiatan adalah para pengurus PATBM Desa Ngalang itu sendiri. Namun untuk kegiatannya yang sifatnya besar seperti pengurus melakukan rekruitmen panitia untuk membantu pelaksanaan program. Berdasarkan hasil penelitian proses rekruitmen panitia pelaksana kegiatan PATBM Desa Ngalang dilakukan dengan mengamati warga yang sekiranya berpotensi. Kemudian pengurus akan menghubungi orang tersebut ataupun orang yang merasa dirinya tertarik dengan aktivitas PATBM Desa Ngalang bisa langsung bergabung dengan menghubungi pengurus. Hal ini dilakukan sebagai langkah untuk melakukan regenerasi terhadap kepengurusan PATBM Desa Ngalang. Sedangkan untuk narasumber atau pemateri direkrut atau dipilih 
berdasarkan tema kegiatan sehingga pemateri bisa berasal dari pihak luar maupun dari pengurus PATBM itu sendiri.

Tahap selanjutnya dalam
pengorganisisasian adalah tahap
penempatan sumberdaya pelaksana. Penempatan sumber daya pelaksana dalam implementasi program didasarkan pada job desc yang telah dibuat dalam kepanitiaaan. Dengan adanya job desc dalam kepanitiaan maka panitia pelaksana kegiatan sudah terbagi tugasnya masing-masing. Namun dalam pelaksanaan di lapangan, penempatan sumber daya pelaksana kegiatan dilakukan secara fleksibel dan lebih ke arah gotong royong walaupun tugas dari setiap anggota sudah ditentukan dalam kepantiaan. Pembagian wilayah kerja dilakukan dengan acak, tidak berdasarkan tempat tinggal dari aktivis. Hal ini dikarenakan untuk memaksimalkan materi yang akan disampaikan agar mudah diterima oleh masyarakat. Karena biasanya ketika yang berbicara itu dari warganya sendiri, materi yang disampaikan lebih susah diterima.

Untuk menjalankan program yang telah dibuat, PATBM Desa Ngalang juga melakukan pengggerakan terhadap para aktivis PATBM. Proses penggerakan ini dilakukan dengan pemberian motivasi dan pembinaan kepada aktivis PATBM. Pemotivasian dilakukan pihak intern dilakukan saat rapat koodinasi dengan saling bertukar pendapat dan informasi sesama aktivis. Dari pihak eksternal, aktivis PATBM juga diberikan pembinaan dan pemotivasian dari pusat, yaitu KPPPA. Proses pembinaan dilakukan ditingkat provinsi, dimana setiap PATBM disuruh untuk mengirimkan perwakilan aktivis. Sedangkan dari tingkat kabupaten, diundang oleh pihak PATBM untuk memberikan motivasi dan masukan.

Reward ataupun punishment merupakan hal yang dapat mendorong para anggotanya untuk bertanggungjawab dan lebih berantusias dalam menjalankan programnya. Namun berdasarkan hasil penelitian hal ini tidak dilakukan oleh PATBM Desa Ngalang. PATBM Desa Ngalang tidak memberikan reward ataupun punishment secara khusus kepada para aktivisnya dikarenakan organisasi ini yang bersifat suka rela. Semua pengurus saling menghargai kesibukan dari pengurus/aktivis lainnya karena memang memiliki kesibukan lain diluar kepengurusannya di PATBM Desa Ngalang. Hal ini sebenarnya perlu dilakukan oleh organisasi atau lembaga agar para aktivis PATBM Desa Ngalang dapat lebih bertanggung jawab terhadap visi dan misi dari PATBM Desa Ngalang.

\section{c. Pengimplementasian Program Lembaga PATBM Desa Ngalang}

Pengimpelementasian program merupakan tahap selanjutnya setelah perencanaan dan pengorganisasian. Pada pelaksanaan program pencegahan tindak kekerasan terhadap anak setiap kegiatan yang diadakan harus memasukan unsur sosialisasi didalamnya. Ada beberapa komponen yang harus diperhatikan untuk kegiatan tersebut diantaranya, proses pembelajaran yang dilakukan, peran narasumber, dan suasana pembelajaran. Berikut ini akan dijelaskan lebih rinci terkait komponen tersebut.

Proses pembelajaran merupakan kegiatan inti dalam program pencegahan tindak kekerasan terhadap anak. Dalam proses pembelajaran ini akan terjadi interaksi antara peserta dan narasumber. Berdasarkan hasil penelitian yang dilakukan oleh peneliti proses pembelajaran di PATBM Desa Ngalang dibagi menjadi empat sesi, yaitu 
pembukaan, acara inti, tanya jawab dan sharing-sharing, penutupan. Pembukaan bisanya dilakukan dengan berdoa bersama. Kemudian acara inti berupa penyampaian materi oleh narasumber, dilanjutkan acara tanya jawab dan sharing-sharing antara narasumber dan peserta terkait materi yang telah disampaikan. Selanjutnya acara ditutup dengan membaca doa bersama.

Narasumber dalam kegiatan yang diselenggarakan oleh PATBM Desa Ngalang berasal dari pengurus PATBM Desa Ngalang itu sendiri dan kerja sama dengan pihak luar. PATBM Desa Ngalang berkerjasama dengan fasilitator PATBM dari kabupaten, puskesmas, kepolisian, dan FPK2 PA untuk menjadi narasumber. Dengan mendatangkan narasumber dari luar diharapkan materi yang disampaikan akan lebih mudah diingat oleh para peserta. Pemilihan narasumber harus memenuhi beberapa kriteria diantaranya menguasai materi yang akan disampaikan dan mampu membangun suasana yang menyenangkan kepada para peserta kegiatan. Peran narasumber dalam kegiatan pencegahan tindak kekerasan terhadap anak cukup baik dalam menyampaikan materi. Hal ini dibuktikan dengan beberapa pendapat peserta kegiatan yang merasa narasumber dapat memberikan materi dengan baik sehingga mudah dipahami peserta. Peserta kegiatan cukup antusias mendengarkan apa yang disampaikan oleh narasumber dan antusias dalam bertanya. Narasumber dapat membangun susana yang menyenangkan dengan mengajukan pertanyaanpertanyaan kepada peserta sehingga peserta tidak merasa bosan dengan materi yang disampaikan.

Suasana pembelajaran yang dilakukan oleh PATBM Desa Ngalang dapat berjalan dengan kondusif. Suasana pembelajaran saat kegiatan diusahakan oleh narasumber dapat kondusif agar apa yang disampaikan dapat diterima dengan baik. Suasana yang kondusif dapat mempengaruhi keterlibatan secara penuh dalam kegiatan yang dilakukan. Agar suasana kondusif narasumber melakukan komunikasi dua arah. Sehingga peserta tidak bosan dengan hanya mendengar materi dari narasumber. Narasumber melakukan komunikasi dua arah dengan cara mengajukan pertanyaan kepada peserta agara ada timbal balik. Pemateri/narasumber juga mampu mengelola susana agar tidak menjenuhkan sehingga peserta bisa fokus dengan materi yang disampaikan. Selain, itu materi yang menarik juga membuat peserta tertarik untuk mendengarkan dan mengikuti kegiatan pembelajaran.

\section{d. Monitoring dan Evaluasi Program PATBM Desa Ngalang}

Monitoring atau pengawasan dilakukan satu kali dalam setahun, yaitu pada awal tahun. Monitoring dilakukan dari pusat, yaitu KPPPA RI dan dari kabupaten, yaitu $\mathrm{DP}_{3} \mathrm{AKBPM} \& \mathrm{D}$. Proses monitoring dilakukan dengan mengumpulkan pengurus PATBM Desa Ngalang dan kelompok sasaran program, yaitu perwakilan warga Desa Ngalang untuk diwawancarai. Monitoring juga dilakukan secara langsung dengan mengamati kondisi masyarakat dan melihat laporan kegiatan apakah kegiatan dapat berjalan sesuai yang direncanakan. Monitoring bertujuan untuk mengontrol dan mengukur keberhasilan program dari PATBM Desa Ngalang agar sesuai dengan tujuan yang telah ditetapkan. Monitoring yang dilakukan memiliki tujuan yang sama seperti yang diungkapkan oleh (Yumari, 2017: 4) yang menyatakan bahwa monitoring digunakan untuk mengumpulkan data dan informasi dari 


\section{Diklus: Jurnal Pendidikan Luar Sekolah, 2 (3), September 2019 - 113}

Ratih Setyawati

sebuah kebijakan/program/kegiatan untuk mengukur keberhasilan kebijakan/ program/kegiatan.

Berdasarkan hasil wawancara pada PATBM Desa Ngalang, kegiatan evaluasi yang dilakukan oleh pengurus PATBM Desa Ngalang hanya sebatas evaluasi program, sedangkan evaluasi pembelajaran tidak dilaksanakan. Evalausi program dilakukan saat rapat koordinasi pengurus setiap bulan setelah pelaksanaan program. Dalam pelaksanannya, evaluasi yang dilakukan berdasarkan observasi pengurus dan melihat notulensi kegiatan yang akan disampaikan dalam rapat koordinasi pengurus tersebut. Kemudian hasil evaluasi program ini digunakan sebagai dasar penentuan program selanjutan. Kegiatan evaluasi pembelajaran dan evaluasi program sebenarnya perlu dilakukan oleh lembaga untuk mengetahui sejauhmana program dapat diterima dan sejauhmana dapat mengubah pengetahuan dan keterampilan dari kelompok sasaran program. Selain itu evaluasi juga dapat dijadikan dasar untuk merumuskan solusi dalam menghadapi kendalakendala yang terjadi. Sehingga dapat memperbaiki program dan meningkatkan keberhasilan programprogram selanjutnya. Evaluasi dilakukan dengan tujuan untuk pengambilan keputuasan apakah program yang dijalankan akan dihentikan, diperbaiki, divariasi atau dikembangkan. Hal ini sesuai dengan pendapat Widyoko (2009: 6) bahwa kegiatan evaluasi merupakan proses yang sistematis dan berkelanjutan untuk mengumpulkan, mendeskripsikan, meginterpretasikan, dan menyajikan informasi tentang suatu program yang digunakan sebagai dasar membuat keputusan dan menyusun laporan selanjutnya.
Kesimpulan dari pemaparan di atas monitoring program perlu dilakukan untuk mengontrol program-program yang telah berjalan sehingga tujuan yang telah ditentukan dapat tercapai. Untuk melakukan monitoring ada berbagai cara yang dapat dilakukan, yaitu melalui wawancara, melihat laporan kegiatan ataupun dengan melakukan pengamatan secara langsung. Hal ini sesuai dengan yang dilakukan oleh PATBM Desa Ngalang. Sedangkan dalam proses evaluasinya, evaluasi program telah dilakukan secara menyeluruh oleh PATBM Desa Ngalang. Namun untuk evaluasi pembelajaran belum dilakukan oleh pihak PATBM Desa Ngalang, sehingga tidak dapat diketahui sejauh mana materi pembelajaran dapat mengubah pengetahuan kelompok sasaran program.

\section{Manfaat Program PATBM Desa Ngalang \\ PATBM Desa Ngalang merupakan} lembaga perlindungan anak yang dilaksanakan secara terpadu, bersinergi dengan masyarakat untuk memberikan edukasi dan pendampingan terkait perlindungan anak dan pemenuhan hakhak anak. Manfaat dari PATBM Desa Ngalang, yaitu:

\section{a. Kesadaran Orang Tua dalam Pemenuhan Hak-Hak Anak \\ Manfaat PATBM Desa Ngalang} salah satunya adalah meningkatnya kesadaran orang tua untuk memenuhi hak-hak anaknya. Kesadaran ini timbul karena adanya pemahaman terhadap pengetahuan yang mereka peroleh. Hal ini sesuai dengan pendapat Coombs dan Ahmed, 1985 (dalam Suryono dan Tohani 2016: 19) tujuan pendidikan nonformal adalah untuk memenuhi kebutuhan pendidikan atau kebutuhan belajar warga masyarakat dimana kebutuhan pendidikan sangat beragam, dengan memberikan pengetahuan, keterampilan 
dan nilai-nilai yang dibutuhkan dalam rangka meningkatkan kualitas kepribadian, meningkatkan kesejahteraan hidup, membangun kehidupan sosial yang dinamis, dan terwujudnya kehidupan berpolitik yang partisipatoris.

Edukasi yang diberikan oleh PATBM Desa Ngalang melalui programprogramnya menambah pengetahuan orang tua mengenai hak-hak anak yang harus mereka penuhi. Peningkatan kesadaran ini diwujudkan dengan pemenuhan hak anaknya, seperti hak rekreasi dan hak mengembangkan potensi diri. Sebagai orang tua, mereka memberikan masukan kepada anaknya untuk mengikuti organisasi/forum anak. Dengan mengikuti organisasi anak akan terbiasa untuk bersosialisasi sehingga mereka memiliki tambahan pengetahuan, memiliki lingkungkan dan kegiatan yang positif. Dengan pemenuhan hak-hak ini berati para orang tua telah memberikan perlindungan terhadap hak-hak anak. Pemahaman seperti ini akan meminimalisir terjadinya tindak kekerasan terhadap anak.

b. Perkembangan Anak dari Segi Kognitif, Segi Sosial, dan Segi Moral

PATBM Desa Ngalang sebagai lembaga pemerhati anak tentunya memiliki peran dalam perkembangan anak. Perkembangan tersebut terutama dalam segi kognitif, sosial dan moral anak melalui berbagai kegiatan yang dilakukan PATBM Desa Ngalang termasuk dalam pendampingan FAD Desa Ngalang. Perkembangan kognitif berkaitan dengan kemampuan seseorang dalam berpikir. Kemampuan ini dilandasi oleh pengetahuan seseorang untuk mencari pemecahan masalah yang ia hadapi. Manfaat PATBM Desa Ngalang dilihat dari aspek perkembangan anak dari segi kognitif, yaitu anak mampu mengutarakan pendapatnya secara kritis, anak bertambah pengetahuannya tentang hak dan perlindungan anak, dan anak memiliki inisiatif untuk melaporkan.

Dilihat dari segi sosial PATBM Desa Ngalang menyumbang kepada anak untuk memiliki pergaulan yang positif, kemampuan beradaptasi dengan lingkungan baru, kepedulian anak terhadap orang lain dan peningkatan kepercayaan diri anak. Dalam pengertiannya perkembangan sosial adalah pencapaian kematangan dalam hubungan sosial. Dengan perkembangan sosial, seorang anak dapat menyesuaikan dirinya dengan kelompok teman sebaya maupun dengan lingkungan masyarakat sekitarnya (Yusuf, 2015: 180). Hal ini akan sangat berdampak positif terhadap kehidupan anak di dalam masyarakat karena anak menjadi lebih dihargai dan diakui keberadaanya di masyarakat tersebut.

Anak sebagai individu ataupun sebagai anggota masyarakat memiliki nilai-nilai yang dianutnya. Nilai yang dijadikan pedoman akan berpengaruh terhadap perilaku anak tersebut. Nilainilai kehidupan yang perlu diinformasikan dan selanjutnya dihayati oleh anak tidak terbatas pada adat kebiasaan dan sopan santun saja, tetapi juga seperangkat nilai seperti keagamaan, nilai perikemanusiaan dan perikeadilan, nilai estetik, nilai etik, dan nilai intelektual dalam bentuk yang sesuai perkembangan anak. Manfaat PATBM Desa Ngalang dalam pembentukan moral anak, yaitu anak memiliki tata krama terhadap orang lain dan ada perubahan akhlak ke arah yang baik. 
Tabel 2. Manfaat Program PATBM Desa Ngalang

\begin{tabular}{|c|c|}
\hline Aspek & Hasil \\
\hline $\begin{array}{l}\text { Kesadaran orang } \\
\text { tua dalam } \\
\text { memenuhi hak } \\
\text { anak }\end{array}$ & $\begin{array}{l}\text { a. Peningkatan } \\
\text { terhadap } \\
\text { kesadaran orang } \\
\text { tua dalam } \\
\text { memenuhi hak- } \\
\text { hak anaknya. Hal } \\
\text { ini ditunjukan } \\
\text { dengan sikap } \\
\text { oran tua untuk } \\
\text { memenuhi hak } \\
\text { untuk rekreasi, } \\
\text { hak diri, } \\
\text { mengembangkan } \\
\text { potensi ki untuk } \\
\text { memberikan } \\
\text { masukan kepada } \\
\text { anaknya una } \\
\text { mengikuti } \\
\text { organisasi/forum } \\
\text { anak. }\end{array}$ \\
\hline $\begin{array}{l}\text { Perkembangan } \\
\text { Anak }\end{array}$ & $\begin{array}{l}\text { b. Segi kognitif: } \\
\text { Anak mampu } \\
\text { mengutarakan } \\
\text { pendapatnya } \\
\text { secara kritis, anak } \\
\text { bertambah } \\
\text { pengetahuannya } \\
\text { tentang hak dan } \\
\text { perlindungan } \\
\text { anak, dan anak } \\
\text { memiliki inisiatif } \\
\text { untuk } \\
\text { melaporkan } \\
\text { tindak kekerasan } \\
\text { terhadap anak. } \\
\text { c. Segi sosial: anak } \\
\text { memiliki } \\
\text { lingkungan } \\
\text { pergaulan yang } \\
\text { positif, } \\
\text { kemampuan } \\
\text { beradaptasi } \\
\text { dengan } \\
\text { lingkungan baru, } \\
\text { kepedulian anak } \\
\text { terhadap orang } \\
\text { lain, dan } \\
\text { peningkatan } \\
\text { kepercayaan diri } \\
\text { anak. } \\
\text { d. Segi moral: anak } \\
\text { memiliki tata }\end{array}$ \\
\hline
\end{tabular}

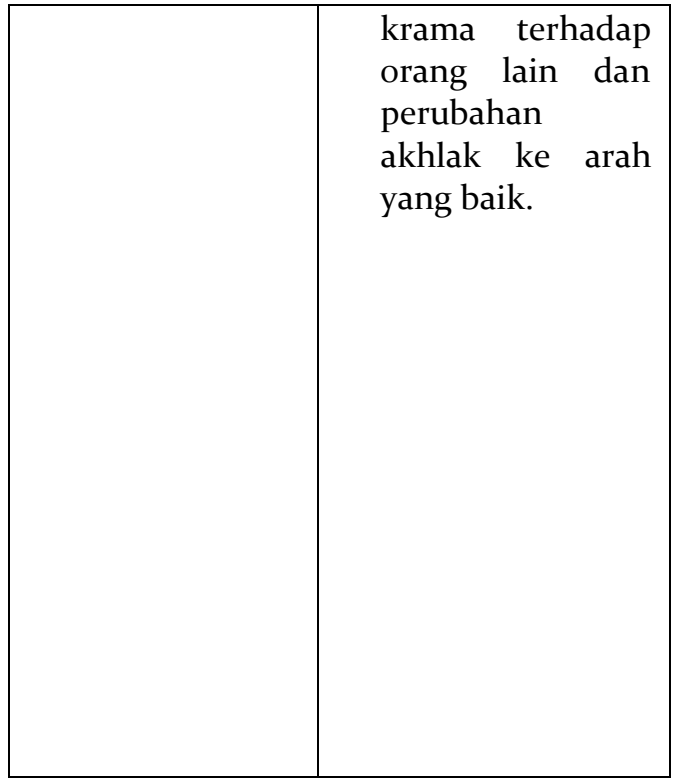

\section{Faktor Penghambat Program PATBM Desa Ngalang}

Faktor penghambat merupakan segala sesuatu yang dapat menghambat suatu kegiatan sehingga mempengaruhi hasil dari kegiatan tersebut. Ada dua faktor yang memungkinkan menghambat kegiatan dalam lembaga, yaitu faktor internal dan faktor eksternal. Lingkungan internal merupakan lingkungan yang berada di dalam organisasi/lembaga tersebut (Siagian, 2012: 64). Lingkungan eksternal merupakan unsur-unsur yang ada diluar organisasi/lembaga.

$$
\text { Pelaksanaan PATBM Desa }
$$

Ngalang tidak terlepas dari hambatan. Dari hasil wawancara dengan beberapa narasumber, penghambat utama dalam pelaksanaan PATBM Desa Ngalang adalah faktor internal, yaitu SDM PATBM Desa Ngalang. Hambatan tersebut terjadi karena waktu yang dimiliki oleh para pengurus PATBM terbatas. Karena pada dasarnya yang tergabung dalam kepengurusan PATBM Desa Ngalang bukanlah orang yang benar-benar free. Mereka mempunyai kesibukan masing-masing. Terlebih dengan sifat lembaga ini adalah bersifat sosial, jadi tidak dapat memaksakan 
pengurusnya untuk selalu aktif dalam setiap kegiatan yang diselenggarakan. SDM yang memiliki kesibukan lain menjadikan pertemuan rutin pengurus secara langsung tidak dapat dilakukan. Untuk mengatasinya pengurus PATBM Desa Ngalang memanfaatkan media sosial untuk berkoordinasi. Sementara itu, segi pendanaan juga menjadi hambatan PATBM Desa Ngalang untuk sering melaksanakan event besar dan pelaksanaan program harus menunggu pencairan dana APBDes. Namun karena kegiatan PATBM Desa Ngalang untuk mengedukasi sifatnya berbasis masyarakat, sehingga hambatan terbatasnya dana diatasi dengan ikut bergabung kegiatan masyarakat yang sudah ada sebelumnya.

Berdasarkan hasil penelitian di lapangan, faktor eksternal tidak ada yang menghambat pelaksanaan PATBM Desa Ngalang. Faktor eksternal seperti kebijakan pemerintah, sosial budaya masyarakat dan perkembangan IPTEK justru mendorong pelaksanaan kegiatan PATBM Desa Ngalang. Kebijakan pemerintah terutama di Desa Ngalang ini sangat memperhatikan kepentingan anak. Terbukti dengan adanya sarana prasarana yang disediakan pemerintah untuk berbagai kegiatan anak dan uidibentukannya lembaga pemerhati anak. Sosial budaya masyarakat Desa Ngalang yang masih menjaga kearifan lokal seperti halnya dengan gotongroyong membuat PATBM Desa Ngalang dapat dengan mudah bersinergi dengan masyarakat. Perkembangan IPTEK yang terjadi sangat membantu PATBM Desa Ngalang dalam mengedukasi masyarakat terkait pencegahan kekerasan terhadap anak dan pemenuhan hak-hak anak.
Tabel 3. Faktor Penghambat Pelaksanaan Program PATBM Desa Ngalang

\begin{tabular}{|c|c|}
\hline Aspek & Hasil \\
\hline $\begin{array}{l}\text { Faktor } \\
\text { Penghambat }\end{array}$ & $\begin{array}{lll}\text { a. } & \text { Kesibukan } & \text { SDM } \\
& \text { PATBM } & \text { Desa } \\
& \text { Ngalang. } \\
\text { b. } & \text { Keterbatasan } \\
\text { pendanaan. }\end{array}$ \\
\hline Solusi & 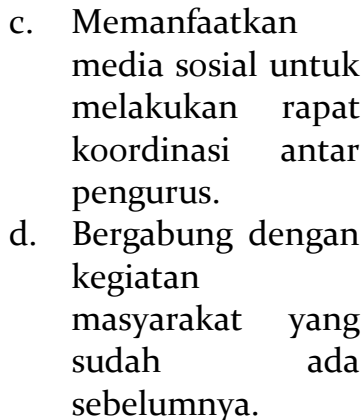 \\
\hline
\end{tabular}

\section{SIMPULAN DAN SARAN Simpulan}

Berdasarkan hasil penelitian dan pembahasan yang telah dilakukan, maka dapat disimpulkan bahwa:

1. Penggelolaan Program PATBM Desa Ngalang, Gedangsari, Gunungkidul

$$
\text { PATBM Desa Ngalang }
$$

menjalankan empat fungsi manajemen program, yaitu perencanaan, pengorganisasian, pengimplentasian, monitoring dan evaluasi. Proses perencanaan program PATBM Desa Ngalang dilakukan dengan baik, yang di awal tahun pada saat rapat kerja dengan melibatkan pengurus dan tokoh-tokoh masyarakat. Kompenen dalam perencanaan program PATBM Desa Ngalang, yaitu: melakukan identifikasi kebutuhan, perumusan dan penetapan program, sumber dana, sarana dan prasarana.

Pengorganisasian dengan cukup baik dengan melakukan penetapan struktur organisasi dan pembagian tugas, perekrutan sumber daya pelaksana program, penempatan sumber daya dalam implementasi program, 
pemotivasian. PATBM penentuan sumber daya manusia yang diperlukan, bagaimana pembagian tugasnya, proses pemotivasian. PATBM Desa Ngalang tidak membuat kebijakan untuk memberikan penghargaan ataupun hukuman kepada para pengurus/aktivis PATBM Desa Ngalang. Komponen yang harus diperhatikan untuk pelaksanaan program meliputi proses pembelajaran yang dilakukan, peran narasumber, dan suasana pembelajaran.

Monitoring PATBM Desa Ngalang dilakukan oleh KPPPA dan $\mathrm{DP}_{3} \mathrm{AKBPM} \& \mathrm{D}$ Kabupaten Gunungkidul setiap satu tahun sekali pada awal tahun. Monitoring dilakukan dengan wawancara langsung pengurus dan masyarakat, mengamati kondisi masyarakat secara langusng dan melalui laporan kegiatan. Evaluasi yang dilakukan oleh pengurus PATBM Desa Ngalang hanya sebatas evaluasi program, sedangkan evaluasi pembelajaran tidak dilaksanakan. Evalausi program dilakukan saat rapat koordinasi pengurus setiap bulan setelah pelaksanaan program. Kemudian hasil evaluasi program ini digunakan sebagai dasar penentuan program selanjutan.

2. Manfaat program PATBM Desa Ngalang

Manfaat dari program yang dilaksanakan adalah terjadi peningkatan kesadaran orang tua dalam pemenuhan hak-hak anak. Sedangkan untuk perkembangan perkembangan anak manfaatnya, yaitu a) segi kognitif, anak mampu mengutarakan pendapatnya secara kritis, anak bertambah pengetahuannya tentang hak dan perlindungan anak, dan anak memiliki inisiatif untuk melaporkan, b) segi sosial, yaitu memiliki pergaulan yang positif, kemampuan beradaptasi dengan lingkungan baru, kepedulian anak terhadap orang lain dan peningkatan kepercayaan diri anak; c) segi moral, yaitu anak memiliki tata krama terhadap orang lain; ada perubahan akhlak ke arah yang baik.

3. Faktor penghambat pelaksanaan program PATBM Desa Ngalang

Faktor penghambat pelaksanaan program PATBM Desa Ngalang terjadi karena faktor internal, yaitu SDM PATBM Desa Ngalang dan keterbatasan pendanaan. SDM yang memiliki kesibukan lain menjadikan pertemuan rutin pengurus secara langsung tidak dapat dilakukan. Untuk mengatasinya pengurus PATBM Desa Ngalang memanfaatkan media sosial untuk berkoordinasi. Sedangkan untuk keterbatasan pendanaan PATBM Desa Ngalang berusaha untuk memaksimalkan kegiatannya melalui bergabung dengan kegiatan-kegiatan masyarakat yang sudah ada sebelumnya.

\section{Saran}

Berdasarkan kesimpulan hasil penelitian mengenai pengelolaan program Perlindungan Anak Terpadu Berbasis Masyarakat (PATBM) Desa Ngalang yang telah diuraikan diatas, maka berikut ini sarannya yang peneliti ajukan:

1. Pengurus PATBM Desa Ngalang diharapkan lebih mengoptimalkan peranannya dalam organisasi.

2. Perlu adanya penambahan aktivis atau pengurus PATBM Desa Ngalang agar program dapat dijalankan lebih intens dan menyeluruh.

3. Pengurus PATBM Desa Ngalang dapat mencari sponsor dengan membuat proposal pengajuan dana untuk kegiatan-kegiatan yang sifatnya memerlukan dana cukup besar.

4. Diharapkan ada evaluasi pembelajaran agar dapat diketahui tingkat pemahaman peserta 
kegiatan/masyarakat terkait materi yang telah disampaikan.

\section{DAFTAR PUSTAKA}

Fuad, N. (2014). Manajemen Pendidikan Berbasis Masyarakat: Konsep Strategi dan Implementasi. Jakarta: Rajawali Pers.

Gultom, Maidin. (2008). Perlindungan Hukum Terhadap Anak Dalam Sistem Peradilan Anak Di Indonesia. Bandung: Refika Aditama.

Kurniawan, Agung. (2005). Transformasi Kebijakan Publik. Yogyakarta: Pembaharuan.

Majid, Abdul. (2008). Perencanaan Pembelajaran (Mengembangkan Standar Kompetensi Guru). Bandung: Refika Aditama.

Marliani, Rosleny. (2016). Psikologi Perkembangan Anak dan Remaja. Bandung: Pustaka Setia.

Republik Indonesia. (2002). UndangUndang Republik Indonesia Nomor 23 Tahun 2002 tentang Perlindungan Anak.
Setyawan, David. (8 Januari 2019). KPAI: 4.885 Kasus Pelanggaran Hak Anak, Terbanyak ABH. www.kpai.go.id. Diakses pada tanggal 31 Januari 2019.

Siagian, S.P. (2012). Manajemen Stratejik. Jakarta : Bumi Aksara.

Sugiyono. (2015). Metode Penelitian Kuantitatif, Kualitatif, dan RED. Bandung: ALFABETA.

Suharto, T. (2005). Konsep Pendidikan Berbasis Masyarakat. Cakrawala Pendidikan, 3, 335.

Suryono, Y., \& Tohani, E. (2016). Inovasi Pendidikan Nonformal. Yogyakarta: Graha Cendekia.

Widyoko. (2009). Evaluasi Program Pembelajaran. Yogyakarta: Pustaka Pelajar.

Yumari, W. (2017). Monitoring dan Evaluasi Pelaksanaan Anggaran. Yogyakarta: CV Budi Utama.

Yusuf, Syamsu. (2015). Psikologi Perkembangan AnakERemaja. Bandung: Remaja Rosdakarya. 